\title{
PROCEEDINGS OF CBU
}

\section{CBU International Conference Proceedings 2014:}

\section{Innovation, Technology transfer and Education}

Editors:

Petr Hájek

Pete Mumanachit

\section{3-5 February 2014}

Prague, Czech Republic

\section{Organized by}

Central Bohemia University, o.p.s., Prague, Czech Republic

Unicorn College s.r.o., Prague

Publisher

Central Bohemia University, o.p.s., Prague, Czech Republic

Proceedings of CBU 1805-9961, Vol. 2

Central Bohemia University is a nonprofit private university.

www.cbuni.cz

International Conference on Innovation, Technology Transfer and Education 2014:

edited by Petr Hájek, Pete Mumanachit, Proc. of CBU Vol. 2,

E-ISSN 1805-9961 (Online)

\section{http://dx.doi.org/10.12955/cbup.v2.676}


As this is a serial book published annually, it has both ISSN and ISBN. ISSN links to whole series of proceedings based on CBU International Conferences while ISBN links to this specific issue in 2014. Each article has also its own unique permanent DOI number which is located on the first page. A digital object identifier (DOI) is a unique alphanumeric string to identify content and provide a persistent link to its location on the internet. All DOI numbers begin with a 10 and contain a prefix and a sufix separeted by a slash. The prefix is number of four or more digits assigned to organizations; the sufix is assigned by the publisher. All articles were peer reviewed.

Please use the following format to cite material from this book:

Author, A., A. \& Author, B., B. (2014). TITTLE OF PAPER. CBU International Conference

Proceedings, 2. doi: Article DOI.

ISBN 978-80-905536-2-0 (Online)

ISSN 1805-9961 (Online)

Published by

Central Bohemia University, o.p.s.

Pod Vodárenskou věží 4,

18200 Praha 8,

Czech Republic

June 30, 2014

Printed in the Czech Republic with ISSN 1805-997X and ISBN 978-80-905536-3-7 (Print).

CBU International Conference Website

www.cbuic.cz, info@cbuni.cz

ojs.journals.cz

Publication of record for individual papers is online in the CBU Digital Library: ojs.journals.cz. This website is used to distribute the articles into various databases. For citing online articles please use

E-ISSN (Online ISSN).

Copyright information:

Authors retain copyright and grant the journal right of first publication with the work simultaneously licensed under a Creative Commons Attribution License (Creative Commons Attribution License 3.0 - CC BY 3.0) that allows others to share the work with an acknowledgement of the work's authorship and initial publication in this journal.

Authors are able to enter into separate, additional contractual arrangements for the non-exclusive distribution of the journal's published version of the work (e.g., post it to an institutional repository or publish it in a book), with an acknowledgement of its initial publication in this journal.

Authors are permitted and encouraged to post their work online (e.g., in institutional repositories or on their website) prior to and during the submission process, as it can lead to productive exchanges, as well as earlier and greater citation of published work (See The Effect of Open Access).

The conference Keynote speakers:

David Hartman, Unicorn College, Academy of Sciences of the Czech Republic, Charles University in Prague,

Veronika Kaplanová, Unicorn College, Prague

Tomáš Kroček, Charles University, Prague

Jan Soumar, Charles University in Prague

Jiří Daněk, Charles University in Prague

Petr Hájek, Central Bohemia University, Prague 
Table of contents

VI Conference chairs

VI Editorial committees

IX Introduction

\section{Economics and Business}

TOTAL QUALITY CUSTOMER SATISFACTION MODEL

Jesús Cruz Álvarez, Fabián López Pérez, Carlos Monge Perry

http://dx.doi.org/10.12955/cbup.v2.440

\section{KNOWLEDGE MANAGEMENT IN INDUSTRY CLUSTERS AS AN INDICATION OF} ENTREPRENEURSHIP.

Bogustaw Bembenek, Teresa Piecuch

http://dx.doi.org/10.12955/cbup.v2.441

MANUFACTURING AND CONTINUOUS IMPROVEMENT AREAS USING PARTIAL LEAST SQUARE PATH MODELING WITH MULTIPLE REGRESSION COMPARISON.

Carlos Monge Perry, Jesús Cruz Álvarez, Jesús Fabián López

http://dx.doi.org/10.12955/cbup.v2.442

A NEW METHODOLOGY ON STRATEGIC PLANNING

Hakan Bütüner

http://dx.doi.org/10.12955/cbup.v2.443

MANAGEMENT OF FOREIGN DIRECT INVESTMENT IN TERMS OF ITS REGIONAL LOCALIZATION IN SLOVAKIA

Rastislav Kotulič, Peter Adamišin, Ivana Kravčáková Vozárová

http://dx.doi.org/10.12955/cbup.v2.444

MANAGEMENT OF SPECIAL FOOD PRODUCT - AN OPPORTUNITY FOR MARKET

EXPANSION IN THE REGION AND EUROPEAN FOOD MARKET.

Mirjana Nedović, Lovro Babić

http://dx.doi.org/10.12955/cbup.v2.445

CONDITIONS OF INVESTMENT DECISION-MAKING IN AREA OF RFID

TECHNOLOGY

Marzena Jankowska-Mihułowicz, Piotr Jankowski-Mihułowicz

http://dx.doi.org/10.12955/cbup.v2.446

INSTITUTIONAL PROBLEMS OF FINANCIAL CAPITAL MOBILIZATION IN MODERN RUSSIAN ECONOMY.

Igor Barhatov, Ekaterina Biruykova, Igor Afanasev

http://dx.doi.org/10.12955/cbup.v2.447 
OPPORTUNISM AND EFFICIENCY OF CONTRACTUAL RELATIONS IN RUSSIAN

CORPORATIONS.

Daria Benz, Elena Kozlova, Elena Silova

http://dx.doi.org/10.12955/cbup.v2.448

ANALYSIS OF VALUE ADDED DISTRIBUTION AND LEVEL OF TRANSACTION COSTS IN THE RUSSIAN CORPORATIONS.

Dmitri Pletnev, Ekaterina Nikolaeva, Zinfira Bitkulova

http://dx.doi.org/10.12955/cbup.v2.449

CHANGES IN INTERNATIONAL BUSINESS FORMS IN THE CONTEXT OF SUSTAINABLE

DEVELOPMENT...

90-96

Stela Zhivkova

http://dx.doi.org/10.12955/cbup.v2.450

FRANCHISE EXPECTATIONS: CASE OF KAZAKHSTAN.

97-106

Raissa Kaziyeva

http://dx.doi.org/10.12955/cbup.v2.451

CONSUMER ETHNOCENTRISM AND CONSUMER ASSOCIATIONS WITH SLOVAK

BRANDS.

$107-112$

Lucia Vilčeková

http://dx.doi.org/10.12955/cbup.v2.452

DO LITHUANIAN HIGHER EDUCATION ACCOUNTING PROGRAMS REFLECT ACCOUNTING HARMONIZATION IN THE EU?.

Dalia Kaupelyte, Renata Legenzova

http://dx.doi.org/10.12955/cbup.v2.453

THE IMPACT OF RESEARCH AND DEVELOPMENT EXPENDITURES ON INNOVATION PERFORMANCE AND ECONOMIC GROWTH OF THE COUNTRY-THE EMPIRICAL EVIDENCE. $119-125$

Ján Huňady, Marta Orviská

http://dx.doi.org/10.12955/cbup.v2.454

MODELING MARKET RISK IN FRONTIER EQUITY MARKETS-EVIDENCE FROM SERBIA

Marko Milojević, Ivica Terzić

http://dx.doi.org/10.12955/cbup.v2.455

ROMANIAN ACHIEVEMENTS IN PETROLEUM INDUSTRY...

$134-141$

Maria Stoicescu, Eugen Mihail Ionescu

http://dx.doi.org/10.12955/cbup.v2.456

EUROPEAN FUNDS MANAGEMENT ANALYSIS-A CASE STUDY OF EUROPEAN SOCIAL FUNDS IN ROMANIA FROM 2007 TO 2013

http://dx.doi.org/10.12955/cbup.v2.457 
COINTEGRATION ANALYSIS OF THE FOREIGN EXCHANGE RATE PAIRS.

Mária Bohdalová, Michal Greguš

http://dx.doi.org/10.12955/cbup.v2.497

\section{Social Sciences}

THE IMPORTANCE OF INTERNAL DIRECTIVES OF THE UNIVERSITY FOR THE INTELLECTUAL PROPERTY PROTECTION.

Andrea Čorejová, Jana Jarošová

http://dx.doi.org/10.12955/cbup.v2.458

PROFESSIONAL DEVELOPMENT AS A MOTIVATOR OF GENERATION Y

$160-168$

Krystyna Kmiotek

http://dx.doi.org/10.12955/cbup.v2.459

EDUCATIONAL POLICIES FOR PROVIDING THE QUALITY OF LIFE

$169-176$

Marina Liga, Tatiana Voronchenko, Yelena Zakharova

http://dx.doi.org/10.12955/cbup.v2.460

DOCTRINAL BASICS OF THE LEGAL TECHNIQUE: COMPARATIVE ANALYSIS WITHIN

THE EUROPEAN LEGAL FRAMEWORK.

Alexander Malko, Margarita Kostenko

http://dx.doi.org/10.12955/cbup.v2.461

CREATIVE WORK UNDER COGNITIVE CAPITALISM CONDITIONS

$186-190$

Viktor Barhatov, Yuner Kapkaev, Oleg Dyachenko

http://dx.doi.org/10.12955/cbup.v2.462

PRESERVATION AND DEVELOPMENT WITHIN THE NATURAL AND SOCIAL

EVOLUTION.

Nadezhda Subbotina

http://dx.doi.org/10.12955/cbup.v2.463

BIOETHICS IN TRANSDISCIPLINARY AND INTERDISCIPLINARY CONTEXT OF POST-

NONCLASSICAL SCIENCE.

Vikotoriya Zasukhina

http://dx.doi.org/10.12955/cbup.v2.464

THE INFLUENCING FACTORS OF CHINESE MYTHOLOGICAL IMAGE CONSTRUCTION AND REPRODUCTION IN THE TRANSBAIKAL REGION.

Artem Zhukov

http://dx.doi.org/10.12955/cbup.v2.465

FORMAL DECENTRALIZATION OF LOCAL GOVERNANCE IN ALBANIA

Roland Lami

http://dx.doi.org/10.12955/cbup.v2.466

TRANSITIONAL PARADIGM AS AN EXPLANATION FOR THE DEMOCRATIZATION PROCESSES.

Gerti Sqapi

http://dx.doi.org/10.12955/cbup.v2.467 
DEVELOPMENT OF FOREIGN LANGUAGE PROFICIENCY ASSESSMENT AND CONTROL METHODS IN HETEROGENIOUS GROUPS OF ADULT LEARNERS IN FURTHER EDUCATION AS A TOOL TO INCREASE STUDENTS' MOTIVATION....

Maria Vladimirovna Zarudnaya, Oksana Ivanovna Barsova

http://dx.doi.org/10.12955/cbup.v2.468

EVOLUTION OF LEGISLATION ON ADOPTION OF CHILDREN IN THE RUSSIAN FEDERATION...

Oksana Petyukova

http://dx.doi.org/10.12955/cbup.v2.469

THE EMPIRICAL DATA COLLECTION AND PROCESSING AS A FACTOR OF RESEARCH

ACTIVITY EFFECTIVENESS..

Nadejda Ogienko, Anastasia Kim

http://dx.doi.org/10.12955/cbup.v2.470

MEDIA DISCOURSE IN THE CONTEXT OF VALUES STUDY

$246-250$

Tatiana Prisyazhnyuk, Elena Zilova

http://dx.doi.org/10.12955/cbup.v2.471

INTERNATIONAL MONETARY FUND AND ITS IMPACT ON IDEOLOGICAL STRUCTURING OF POLITICAL PARTIES

251-255

Roland Lami

http://dx.doi.org/10.12955/cbup.v2.472

REGULATION OF THE ASYMMETRY IN SPATIAL SOCIAL AND ECONOMIC DEVELOPMENT OF THE WEST KAZAKHSTAN OBLAST...

Eduard Imashev

http://dx.doi.org/10.12955/cbup.v2.479

UTILIZATION OF INTERNET SOCIAL MEDIA SITES: STUDENTS' PERSPECTIVE.. $\quad .266-275$ Olivera Grljević, Zita Bošnjak

http://dx.doi.org/10.12955/cbup.v2.484

MECHANISMS FOR SCIENTIFIC RESEARCH COMMERCIALIZATON: AN INDUCTIVE

ASPECT $.276-282$

Alexander Ermakov

http://dx.doi.org/10.12955/cbup.v2.485

SOCIAL ADAPTATION OF PEOPLE WITH DISABILITIES

$283-287$

Marina Sadovski

http://dx.doi.org/10.12955/cbup.v2.486

\section{Medicine and Pharmacy}

THE IMPACT OF THE ENZYME STEROID $5 \alpha$-REDUCTASE 2 DEFICIENCY ON UROGENITAL BIRTH DEFECT IN MALES.

Livia-Irina Olaru

http://dx.doi.org/10.12955/cbup.v2.473

REVIEW OF HOSPITAL MANAGER'S COMPETENCIES IN ASTANA

Ayagyoz Umbetzhanova, Gulmira Derbissalina, Vitaliy Koikov, Lyazzat Karsakbayeva, Nasikhat Nurgaliyeva, Dina Akhmetova, Bibinur Ibraimova, Zhanagul Bekbergenova, Dameli Kassimova http://dx.doi.org/10.12955/cbup.v2.474 
DIVERSITY OF CD1A POSITIVE CELLS IN CASE OF 25-HYDROXYVITAMIN D

DEFICIENCY IN PATIENTS WITH METABOLIC SYNDROME.

299-306

Jana Janovska, Julia Voicehovska, Regina Kleina, Janis Kisis, Raimonds Karls, Olga Zubova, Sergejs Babikovs

http://dx.doi.org/10.12955/cbup.v2.475

ANTI-TUMOR ACTIVITY OF BACTERIAL LECTIN AND 5-METHYLURACIL

ADDUCT

$307-312$

Elena Welchinska

http://dx.doi.org/10.12955/cbup.v2.476

INVESTIGATIONS OF THE INFLUENCE OF SUFAN ON MYOCARDIAL METABOLISM IN

CASES OF EXPERIMENTAL HEART FAILURE

Iryna Nizhenkovskaya

http://dx.doi.org/10.12955/cbup.v2.477

INCREASE IN THE ROLE OF PHARMACIST AS A PROFESSIONAL UNDER THE CONDITIONS OF THE BOLOGNA SYSTEM IN UKRAINE.

Vitaliy Moskalenko, Iryna Nizhenkovskaya, Elena Welchinska

http://dx.doi.org/10.12955/cbup.v2.478

\section{Natural Sciences and ICT}

METHODS OF EXPERIMENTAL VERIFICATION OF STEINER THEOREM IN PHYSICAL PRACTICUM AND LABORATORY WORK.

Zharilkasin Iskakov

http://dx.doi.org/10.12955/cbup.v2.480

CRITICAL FACTORS AFFECTING THE UTILIZATION OF CLOUD COMPUTING..

Alberto Daniel Salinas Montemayor, Jesús Fabián Lopez, Jesús Cruz Álvarez

http://dx.doi.org/10.12955/cbup.v2.481

\section{TURKISH TRANSLATION COMPANIES' USE OF COMPUTER ASSISTED TRANSLATION}

TOOLS

Halil İbrahim Balkul, Hüseyin Ersoy

http://dx.doi.org/10.12955/cbup.v2.482

COLOR CHANGE-MASS LOSS CORRELATION FOR HEAT-TREATED WOOD.....

Cristina Marinela Olarescu, Mihaela Campean

http://dx.doi.org/10.12955/cbup.v2.483 


\section{Conference chairs}

Petr Hajek, Central Bohemia University, Prague, Czech Republic

David Hartman, Unicorn College, Academy of Sciences of the Czech Republic, Charles University in Prague, Czech Republic

\section{Editorial committees}

\section{Editor-in-chief}

Dr. Petr Hajek, Vice-rector, Central Bohemia University, Prague, Czech Republic

\section{Editors}

Pete Mumanachit, Central Bohemia University

\section{Economics and business section committee}

Dr. Petr Hajek, Vice-rector, Central Bohemia University, Prague, Czech Republic

Prof. Drahomír Jančík, Institute of Economic and Social History, Faculty of Arts, Charles University, Prague \& Faculty of Business Administration, University of economics in Prague, Czech Republic

Prof. Jiř́ Kleibl, rector of Unicorn College, Prague, Faculty of Business Administration, University of Economics, Prague, Czech Republic

Assoc. Prof. Miloš Kaňka, Faculty of Informatics and Statistics University of Economics in Prague \& The College of Polytechnics Jihlava, Czech Republic

Dr. Akram Jalal Karim, chairman of the Management Information System Department of College of Business and Finance at Ahlia University, Manama, Bahrain

Dr. Kholnazar Amonov, member of the board, Central Bohemia University, Prague, Czech Republic Assoc. Prof. Murtaz Kvirkvaia, Dean of the Faculty School of Business and Management, Grigol Robakidze University, Georgia

Hana Kristová, Senior Auditor, Deloitte, Prague, Czech Republic

Dr. Viktor Korček, Senior Management and Marketing Consultant \& East-African Project Manager, Prague, Czech Republic

Prof. Pacha Malyadri, Principal, Government Degree College, Osmania University, Hyderabad, Andhra Pradesh, India

Dr. Quang Van Tran, Faculty of Finance and Accounting, University of Economics in Prague, Czech Republic

Prof. Miroslav Tuček, retired professor, Banking expert, University of Economics in Prague, Czech Republic

Assoc. Prof. Kumaraj Sundar, Commerce Wing, Directorate of Distance Education, Annamalai University, India

Assoc. Prof. Jan Čadil, Unicorn College, Prague and Vice-Rector for research and science, Banking Institute/College of Banking, Prague, Czech Republic

Khaled Zidan Ph.D., Finance department, Faculty of Economics and Social Studies, An-Najah

National University, Nablus, Palestine

Dr. Eva Vašková, Victor Pavlik Lawyers LLC. \& Prague Faculty of Law, Charles University in Prague, Czech Republic

Lukáš Horák, CEO's Strategic Analyses Department, Ceska Pojistovna Insurance Group Prague, Czech Republic

Vaidotas Matutis, State Tax Inspectorate, Ministry of Finance, Vilnius, Lithuania

Dr. Michal Brožka, Fixed-Income analyst Macroeconomics - Research Department Raiffeisenbank, Prague, Czech Republic

Patrik Just, Accounting and Law Specialist, Manifold Group, Plzeň, Czech Republic 
Tomáš Voplakal, Charles University in Prague \& Faculty of Finance and Accounting, University of Economics in Prague \& Ernst and Young, Transaction Advisory services department, Czech Republic Valentina Shapoval, Department of Corporate Economics, National Mining University Dnepropetrovsk, Ukraine

Dr. Jan Vorlíček, Unicorn College \& College of information Management and Business Administration, Prague, Czech Republic

Dr. Eva Kaňková, University of Economics in Prague, Czech University of Life Sciences, Czech Republic

Zuzana Svobodová, Department of Management and Marketing (ŠAVŠ), Škoda Auto University, Mladá Boleslav, Czech Republic

Jerome Dumetz, Cross Cultural Management Specialist working in Paris, Prague, Moscow and SanktPeterburg, organization Clamart, Paris, France

Assoc. Prof. Tomáš Pavelka, Faculty of Business Administration, University of Economics in Prague, Czech Republic

\section{Social Sciences section committee}

Prof. Nino Kemertelidze, Vice-rector of Grigol Robakidze University (Heading Scientific Research Management Centre and Center of International Integration), Tbilisi, Georgia

Prof. Eduard Kubů, Faculty of Arts, Charles University \& University of Economics in Prague \& Unicorn College, Prague, Czech Republic

Dr. Eva Vašková, Victor Pavlik Lawyers LLC. \& Prague Faculty of Law, Charles University in Prague, Czech Republic

Salih Seyhan, Communication Faculty, Journalism Department, Ataturk University, Turkey

Prof. Mikheil Gogatishvili, Programme leader of Public Administration, Social and Political sciences, Grigol Robakidze University, Tbilisi, Georgia

Prof. Arta Musaraj, Academicus-International Scientific Journal, Deputy Defence Minister, EtcEntrepreneurship Training Center, ex-rector of University of Pavaresia, Albania

Prof. Petr Marek, Department of Finance and Business Valuation, Executive board member of Acta Oeconomica Pragensia, University of Economics in Prague, Czech Republic

Dr. Alexander Lesnik, Vice-rector, University of Economics and Management, Czech Republic

Pavel Král, Faculty of Management, University of Economics in Prague, Czech Republic

Prof. Milan Žák, Rector, University of Economics in Prague, Czech Republic

Daniel Tácha, editor-in-chief of Make Money, a journal published by Financial Media Group, Prague, Czech Republic

\section{Medicine and Pharmacy section committee}

Dr. Jana Staňurová, Fakultät für Biologie und Vorklinische Medizin, Universität Regensburg, Germany Dr. Nakul Vinod Karkare, Orthopaedic surgeon and biomaterials engineer. Loma Linda, CA, United States

Dr. Eliška Potluková, 3rd Department of Medicine - Department of Endocrinology and Metabolism, First Faculty of Medicine, Charles University in Prague and General University Hospital in Prague, Czech Republic

Assoc. Prof. Ekaterine Chkhartishvili, Human Histology and Embryology Department, AIETI Medical School (David Tvildiani Medical University), Pediatrician, Intensive Care Department, No.1 Pediatric Clinic, Tbilisi, Georgia

Prof. Liana Gogiashvili, Head of the Experimental Pathology Department, A. Natishvili Morphology Institute, Tbilisi, Georgia

Lucie Pieckova, Faculty of Food and Biochemical Technology Institute of Chemical Technology Prague (VSCHT Chemical University), Czech Republic 
Dr. Eva Tůmová, 3rd Department of Medicine - Department of Endocrinology and Metabolism, First Faculty of Medicine, Charles University in Prague and General University Hospital in Prague, Czech Republic

Kateřina Bubáková, Faculty of Biomedical Engineering Czech Technical University in Prague; Motol University Hospital, Prague, Czech Republic

Assoc. Prof. Izzet Yavuz, Faculty of Dentistry, University of Dicle in Diyarbakir, Turkey

Ondřej Lešetický, Department of Management (focus on Medical services), University of Economics in Prague, Czech Republic

Stanislav Janák, Production Director, Škrobárny a.s., Pelhřimov, Czech Republic

Dr. Helena Kristova, Lead clinical research associate, Chiltern International, Prague, Czech Republic

Prof. Olga Reshetnikova, Medical Faculty, Lugansk State Medical University, Ukraine

\section{Natural Sciences and ICT section committee}

Dr. Václav Nevrlý, Institute of Thermomechanics, Academy of Sciences of the Czech Republic; Faculty of Safety Engineering, VŠB-Technical University of Ostrava, Czech Republic

Dr. David Hartman, Head of IT department, Unicorn College, Prague, \& Institute of Computer Science, Academy of Science of the Czech Republic, \& Department of Applied Mathematics, Charles University, Prague, Czech Republic

Assoc. Prof. Zdeněk Zelinger, J. Heyrovský Institute of Physical Chemistry, Academy of Sciences of the Czech Republic, Prague, Czech Republic

Dr. Petr Bitala, Department of Fire Protection, Faculty of Safety Engineering, VŠB-Technical University of Ostrava, Czech Republic

Barbora Baudišová, Laboratory for Risk Research and Management, Faculty of Safety Engineering, \& Energy research center, VŠB-Technical University of Ostrava, Czech Republic

Jan Ptáček, Headmaster of the High School of Chemistry in Pardubice, Czech Republic

Dr. Jan Kamenický, Institute of new technologies and applied informatics, Faculty of Mechatronics, Informatics and Interdisciplinary studies, Liberec Technical University, Czech Republic

Lenka Hrušková, Institute of geochemistry, mineralogy and mineral resources, Faculty of Science, Charles University in Prague, Czech Republic

Dr. Viktor Goliáš, Institute of geochemistry, mineralogy and mineral resources, Faculty of Science, Charles University in Prague, Czech Republic

Dr. Oldřich Mužík, Research Institute of Agricultural Engineering, Prague, Czech Republic Ladislav Torčík, CEO, NanoTrade Ltd., Olomouc, Czech Republic

Prof. Bohumil Havrland, Faculty of Tropical AgriSciences, \& editor-in-chief of Agricultura Tropica Et Subtropica an indexed journal of Czech University of Life Sciences, Prague, Czech Republic

Libor Voplakal, Faculty of Transportation Sciences, Czech Technical University in Prague, Czech Republic

Michal Kökörčený, Head of Project Management Department (IT projects), Frederiksgroup \& Unicorn College, Prague, Czech Republic

Dr. Yılmaz Uyaroğlu, Electrical \& Electronics Engineering Department, Engineering Faculty, Sakarya University, Sakarya, Turkey

Dr. Ahmet Çifci, Electrical and Energy Department, Burdur Mehmet Akif Ersoy University, Burdur, Turkey

Dr. Uğur Erkin Kocamaz, Computer Technologies Department, Uludağ University, Karacabey, Turkey 


\section{Introduction}

We had the great honor of organizing the CBU International Conference 2014 (CBUIC 2014): Innovation, Technology transfer and Education in Prague, Czech republic. It was truly a great pleasure for us to greet a lot of participants from many different countries attending CBUIC 2014! We firmly believe that the conference will become an important international event in the field of crossindustry discussion about innovations in Education and Science and crossindustry cooperation.

CBUIC 2014 was organized by Central Bohemia University and Unicorn College, Prague, Czech Republic. Proceedings were published by Central Bohemia University.

5 cooperating organizations supported the conference. There were 48 papers accepted for presentation at CBUIC 2014, contributed by over 95 authors from more than 10 countries. We had four plenary speeches and several well-known scientists and experts, to give invited talks at different sessions.

The purpose of CBUIC 2014 was to provide a forum for the participants to report and review innovative ideas, with up-to-date progress and developments, and discuss the novel approaches to application in the field of their own research areas and discuss challenges of doing science and education.

We sincerely hope that the exchange of ideas on doing research, science and improving education will help the participants, and international cooperation sharing the common interest will be enhanced.

On behalf the Organization Committee of CBUIC 2014, we would like to heartily thank our cooperating organizations for all they have done for the conference. We would also like to thank the authors for their contribution to the proceedings; the participants and friends of CBUIC 2014, for their interest and efforts in helping us to make the conference possible; and the Editorial boards for their effective work and valuable advice, especially the CBUIC 2014 Secretariat and the CBU staff, for their tireless efforts and outstanding services in preparing the conference and publishing the Proceedings.

Petr Hájek, Central Bohemia University

David Hartman, Unicorn College

Conference chairs 